\title{
Population dynamics of Megapitaria squalida (Bivalvia: Veneridae) at Magdalena Bay, Baja California Sur, Mexico
}

\author{
Tanja Schweers ${ }^{1}$, Matthias Wolff ${ }^{2}$, Volker Koch $^{3}$ \& Francisco Sinsel Duarte ${ }^{4}$ \\ 1 Wiesenweg 187, 27257 Sudwalde, Germany; taschweers@web.de \\ 2 Center for Tropical Marine Ecology (ZMT), University of Bremen, Fahrenheitstrasse 6, 28359 Bremen, Germany; \\ matthias.wolff@zmt-bremen.de \\ 3 Universidad Autónoma de Baja California Sur (UABCS), Depto. Biol. Marina, Apdo. 19-B, Carretera al Sur, km 5.5, \\ La Paz, B.C.S., C.P. 23080, Mexico; vokoch@uabcs.mx \\ 4 Campo 13, Estero San Buto, Bahía Magdalena, domicilio conocido, B.C.S., Mexico
}

Received 30-V-2005. C Corrected 12-I-2006. Accepted 23-V-2006.

\begin{abstract}
The population dynamics of an intertidal population of Megapitaria squalida was studied from September 2002 to February 2003 in Bahía Magdalena, Mexico. To obtain information about the artisanal and recreational fishery of $M$. squalida, local fishermen at different parts of the bay were interviewed. Clam densities were determined at one unexploited and two exploited sites along perpendicular transects from the shore line. Average clam density was $2.01 \pm 1.41 \mathrm{ind} / \mathrm{m}^{2}$, densities did not differ significantly between the three sampling sites. The length-total mass relation was $\mathrm{M}_{\text {tot }}=0.0001 * \mathrm{SL}^{3.1644}\left(\mathrm{r}^{2}=0.9804, \mathrm{n}=92\right)$ and the length-tissue mass relation was $\mathrm{M}_{\mathrm{tis}}=0.0002 * \mathrm{SL}^{2.7144}\left(\mathrm{r}^{2}=0.945, \mathrm{n}=92\right)$. Von Bertalanffy-growth parameters were determined using marked individuals. Strong interindividual and also seasonal differences in growth were observed. Average annual values were: $\mathrm{K}=0.655, \mathrm{~L} \infty=83 \mathrm{~mm}$. Since $M$. squalida can reach a shell length of more than $135 \mathrm{~mm}$ in deeper waters, it is necessary to consider intertidal and subtidal populations separately. Average total mortality (Z) was $1.61 \mathrm{y}^{-1}$. No fishing mortality was calculated because total mortality $\mathrm{Z}$ at the unexploited control site was higher than $\mathrm{Z}$ at the exploited sites. It appears that $M$. squalida migrates into deeper water with increasing shell length, as average shell length increased at lower tidal levels and marked specimens showed a clear migration towards deeper waters. As yet no overexploitation could be found in the study area. Rev. Biol. Trop. 54 (3): 1003-1017. Epub 2006 Sept. 29.
\end{abstract}

Key words: Megapitaria squalida, Veneridae, population dynamics, intertidal, Bahía Magdalena, México.

The clam Megapitaria squalida (Sowerby 1835) is a sediment-burrowing filter-feeder that inhabits sandy sediments from the intertidal to depths of about $160 \mathrm{~m}$ (Keen 1971). It is distributed from Scammon's Lagoon, Baja California $\left(27^{\circ} \mathrm{N}, 113^{\circ} \mathrm{W}\right)$ through the Gulf of California as well as along the Pacific coast south to Mancora, Peru ( $6^{\circ} \mathrm{S}, 81^{\circ} \mathrm{W}$ ) and grows to a shell length of about $135 \mathrm{~mm}$ (Keen 1971). Little is known about its biology and ecology, few studies have focused on distribution (Baqueiro-Cárdenas and Stuardo 1977, Baqueiro-Cárdenas 1979, Baqueiro-Cárdenas et al. 1982, Gutiérres-Barreras et al. 1998), reproduction (Singh-Cabanillas et al. 1991, Villalejo-Fuerte et al. 1996, Villalejo-Fuerte et al. 2000, Baqueiro-Cárdenas and AldanaAranda 2000) and growth (Castro-Ortiz et al. 1992) of M. squalida in Northwestern Mexico. The species has separate sexes (VillalejoFuerte et al. 2000), spawning and recruitment were observed throughout the year with one or two peaks, and the reproductive cycle varied between different sites (Baqueiro-Cárdenas and Stuardo 1977, Villalejo-Fuerte et al. 2000). The smallest specimen with gametogenesis had a shell length of $41.7 \mathrm{~mm}$ (Baqueiro-Cárdenas and Stuardo 1977). Natural predators of $M$. 
squalida are gastropods (e.g. Hexaplex erythrostomus, $H$. nigritus, Polinices spp.), crabs (Callinectes bellicosus), sea stars (Asteropecten armatus), shore birds and fishes, among others (pers. obs.).

Chocolate clams are an important component of the benthic community in Bahía Magdalena, a shallow and highly productive coastal lagoon (Cruz-Agüero et al. 1994) located on the west coast of Baja California Sur (Fig. 1). The black chocolate clam is supporting an artisanal and recreational fishery in the region. It is harvested by divers in depths of 2$10 \mathrm{~m}$ using Hooka equipment and is also hand collected during spring low tides on exposed intertidal sand flats. Clams are either gathered for personal consumption or sold on the local and regional market. The shell is sometimes used for crafts and jewellery (Castro-Ortiz et al. 1992). However, there is no quantitative data on zonation, size distribution, biomass, growth and mortality available for this species and nothing is known about the present state of the fishery. The overall objective of this study was thus to study the population dynamics of M. squalida in Bahía Magdalena. Specifically, the following research questions were addressed:

- What is the population density and biomass of $M$. squalida at one unexploited and two exploited areas?

- What is the population size structure in the area and how does it change with water depth?

- What are the growth and mortality rates of $M$. squalida and how is growth influenced by environmental conditions?

- What is the local fishermens knowledge about the past and present level of the fishery?

The study is based on a six months field work conducted in the mangrove channel Estero San Buto near Puerto San Carlos, Baja California Sur. Sampling was done at the intertidal zone, which is also the main fishing area for the recreational fishery. Sampling circles were searched for specimens of $M$. squalida to obtain data on the population size structure, density and biomass. Growth parameters were determined from tagging data. The lengthconverted catch curve was used to estimate total mortality Z. Transects were sampled perpendicular to the shoreline to test the hypothesis, that clam size increases with the water depth. Migration was observed with tagged specimens. Oxygen content, temperature and turbidity of the water was recorded over the study period. Local fishermen were interviewed to obtain qualitative data about the chocolate clam fishery.

\section{MATERIALS AND METHODS}

Study area and sampling sites: Bahía Magdalena (Fig. 1), is located between $24^{\circ} 15^{\prime}$, $\mathrm{N}$ and $25^{\circ} 20^{\prime} \mathrm{N}$, and $111^{\circ} 30^{\prime} \mathrm{W}$ and $112^{\circ} 15^{\prime}$ $\mathrm{W}$ on the Pacific coast of Baja California Sur, Mexico. This coastal lagoon system can be divided into three different areas: the northwestern zone has an irregular form and is mainly composed of intertidal and shallow areas and relatively narrow mangrove channels with an average water depth of $3.5 \mathrm{~m}$; the central zone, that is actually called Bahía Magdalena, is connected with the open ocean through a wide mouth (40 m deep, $4 \mathrm{~km}$ wide), whereas the

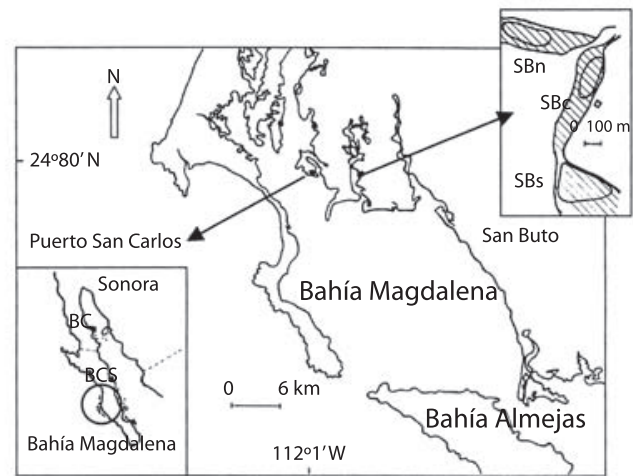

Fig. 1. Bahía Magdalena and sampling sites at Estero San Buto $(\mathrm{SBc}=$ SBcontrol, $\mathrm{SBn}=$ SBnorth, $\mathrm{SBs}=$ SBsouth). Scattered areas represent exposed sandflats. Bahía Magdalena, Mexico,. 2002-2003. 
connection to the ocean of the southern part, called Bahía Almejas, is narrow and shallow. Bahía Magdalena and Bahía Almejas are connected trough a channel of $2.5 \mathrm{~km}$ width and a maximum depth of $10 \mathrm{~m}$ (Alvarez-Borrego et al. 1975). Tides are mixed-semidiurnal with a range of about $2 \mathrm{~m}$. At low tides, wide stretches of mud and sand flats are exposed.

M. squalida can be found in most parts of the bay on sand flats as well as in deeper waters. For the present study one unexploited and two exploited sampling sites were chosen at Estero San Buto, a mangrove channel near the town of Puerto San Carlos (Fig. 1). The exposed sand flat areas at the sites can reach widths of about $200 \mathrm{~m}$ at spring low tides. The sediment is sandy, with varying degrees of coverage with shells and algae and slightly elevated ridges one to several meters wide. The unexplotited site was located near an aquaculture farm. The two exploited sites were located $500 \mathrm{~m}$ north and $500 \mathrm{~m}$ south of the unexploited site. Therefore the sites are referred to as SBcontrol, SBnorth and SBsouth which were compared in terms of population density, size-frequency distributions, biomass, growth and mortality rates.

Density and size distribution: The sampling at the sites was done in the mid- and low-intertidal during spring tide days from September 2002 to February 2003. SBnorth and Sbsouth were sampled at the time of new moon and Sbcontrol to the time of full moon resulting in monthly sampling for each site. 8-16 randomly allocated circles $\left(6 \mathrm{~m}^{2}\right)$ were searched monthly for chocolate clams $>30 \mathrm{~mm}$ at each site. Specimens $<30 \mathrm{~mm}$ could not be reliably detected with this method and were thus not considered. To find the clams, the circles were searched for the typically shaped holes made by their siphons and by stepping next to them. Usually, $M$. squalida would squirt out water when closing the shell, and the clams where then dug out by hand. The number of individuals of $M$. squalida per circle were counted and the shell length of each clam was determined with callipers from the anterior to the posterior end of their shells to the nearest $\mathrm{mm}$. The average density \pm standard deviation of $M$. squalida at each site was calculated by averaging over all replicate samples.

These values were corrected for sampling efficiency that was determined as follows: Six circles were dug out completely with a shovel after the 'normal' sampling was completed. The percentage of additional clams found in a circle was calculated as:

$$
\mathrm{P}=\left(100 /\left(\mathrm{N}_{1}+\mathrm{N}_{2}\right)\right) * \mathrm{~N}_{2}
$$

with $\mathrm{P}=$ percentage of additional individuals; $\mathrm{N}_{1}=$ number of individuals per circle, found with 'normal' sampling; $\mathrm{N}_{2}=$ number of additional individuals per circle.

Using the average value $\left(\mathrm{P}_{\mathrm{av}}\right)$ from the six replicates, the sampling efficiency (SE) was calculated as follows:

$$
\mathrm{SE}=100 \%-\mathrm{P}_{\mathrm{av}}
$$

with $\mathrm{SE}=$ sampling efficiency; $\mathrm{P}_{\mathrm{av}}=$ average percentage.

Size frequency histograms using length classes of $5 \mathrm{~mm}$ were constructed from the length measurements for each site at each sampling date. The average densities of the three sampling sites were compared using an one way ANOVA.

Length-mass relations: A total of 92 specimens were collected during regular sampling at the three different sites and frozen alive at $-20{ }^{\circ} \mathrm{C}$. Later, the total weight of the whole organism, weight of the soft parts and the shell separately were determined with an accuracy of $0.01 \mathrm{~g}$. Shell length was measured with callipers with an accuracy of $0.1 \mathrm{~mm}$. Length-total mass relation and length-tissue mass relation were calculated:

$$
\mathrm{M}=\mathrm{a} * \mathrm{~L}^{\mathrm{b}}
$$

with $\mathrm{M}=$ mass and $\mathrm{L}=$ shell length 
Biomass in each sample was calculated by calculating the mass of each individual using the length-mass relations.

Growth: 159 chocolate clams were marked with a scratch code made with an hacksaw. The scratches were coloured with red nail-polish and coated with super glue. The clams were kept in fenced areas (corrals with $2 \mathrm{~cm}$ mesh buried about $10-15 \mathrm{~cm}$ ) of $0.25,1$ and $4 \mathrm{~m}^{2}$ size at the intertidal zone at an unexploited area to prevent escape of the marked clams. Densities in the corrals were higher than natural densities of $M$. squalida. However, the abundant burrowing clam Chione californensis was excluded from the corrals, thus the total clam density was similar to that found in the field. The shell length was measured monthly using callipers with an accuracy of $0.1 \mathrm{~mm}$. The von Bertalanffy growth equation (VBGE) was used to describe the growth of the clams (Gulland 1988):

$$
\mathrm{L}_{\mathrm{t}}=\mathrm{L}_{\infty}\left(1-\mathrm{e}-\left(\mathrm{K}\left(\mathrm{t}-\mathrm{t}_{0}\right)\right)\right.
$$

with $\mathrm{L}_{\mathrm{t}}=$ length at time $\mathrm{t} ; \mathrm{L}_{\infty}=$ asymptotic length; $\mathrm{K}=$ growth constant; $\mathrm{t}_{0}=$ age at length 0 (considered as zero).

To calculate the parameters of the VBGE, the Munro plot was used (Munro 1982):

$$
\mathrm{K}=\ln \left(\mathrm{L}_{\infty}-\mathrm{L}_{1}\right) \ln \left(\mathrm{L}_{\infty}-\mathrm{L}_{2}\right) /\left(\mathrm{t}_{2}-\mathrm{t}_{1}\right) \text {. }
$$

with $\mathrm{K}=$ growth constant; $\mathrm{L}_{\infty}=$ asymptotic length; $\mathrm{L}_{1}=$ length at tagging; $\mathrm{L}_{2}=$ length at recapture; $t_{2}-t_{1}=$ time interval between tagging and recapture.

This plot requires a fixed input-value for ' $\mathrm{L}_{\infty}$ '. It leads to individual daily ' $\mathrm{K}$ '-values for each specimen. The ' $\mathrm{L}_{\infty}$ ' was selected which minimized the variance around the mean ' $\mathrm{K}$ 'value. The values obtained were multiplied with 365 to obtain the annual growth constants ' $K$ '. To compare the growth constants of different length classes at different months, the average ' $\mathrm{K}$ '-values of length class-groups of
$10 \mathrm{~mm}$ (beginning with the class $0-9.9 \mathrm{~mm}$ ) at every month were calculated. In addition, the average ' $K$ '-value of all measurements was determined and a growth curve was calculated. All calculations were done using the computer program FISAT II (Gayanilo et al. 1994).

To enable comparisons of the growth performances of specimens at different sampling sites and also with other bivalve species, the growth performance index was calculated from the average growth parameter estimates (Pauly and Munro 1984):

$$
\phi=\log 10 \mathrm{~K}+2 * \log 10 \mathrm{~L}_{\infty}
$$

with $\mathrm{K}=$ growth constant and $\mathrm{L}_{\infty}=$ asymptotic length.

Mortality: To calculate the instantaneous annual mortality rate ' $\mathrm{Z}$ ' the length converted catch curve was applied to the pooled length frequency data using the estimated growth parameters from the tagging experiment. The calculation was done with the program FISAT II. 'Z' corresponds to the negative slope of the linear regression of the descending arm of the catch curve (Gayanilo et al. 1994):

$$
\ln \left(\mathrm{N}_{\mathrm{i}} / \Delta \mathrm{t}_{\mathrm{i}}\right)=\mathrm{a}+\mathrm{b} * \mathrm{t}_{\mathrm{i}}
$$

with $\mathrm{N}=$ number of specimens in length class $\mathrm{i} ; \Delta \mathrm{t}=$ time needed for the clam to grow trough length class $\mathrm{i}$; $\mathrm{T}=$ relative age (computed with $\mathrm{t}_{0}=0$ ) corresponding to the midlength of class $\mathrm{i} ; \mathrm{b}=$ estimate of $\mathrm{Z}$.

' $\mathrm{Z}$ ' was calculated for each site and for the complete data set.

Vertical zonation: At each sampling site, transects were sampled perpendicular to the shoreline. The seaward mangrove edge was chosen as a starting point. Beginning at this point, every $20 \mathrm{~m}$ three sampling circles $\left(6 \mathrm{~m}^{2}\right)$ were searched for specimen of $M$. squalida (see above) down to the water line at low tide. The mean lengths of the clams at the different transects (20, 40, 60 and $80 \mathrm{~m})$ were compared using one way ANOVA. 
Migration: 25 clams were tagged as described above and released close to a marked starting point in the mid-low intertidal. After 69 and 143 days, the area around the release point was searched for marked clams and their distance and direction from the release mark was measured.

Monitoring environmental conditions: Throughout the study period, oxygen, temperature and turbidity were measured. Dissolved oxygen content of the water was measured twice every week using Winkler-titration at the time of sunrise and sunset. The samples were taken at the water line near SBcontrol. Morning and evening values were averaged to a mean daily value. For longterm observation of the sediment temperature in ${ }^{\circ} \mathrm{C}$, a data-logger (Tidbit ${ }^{t m}$ ) was dug into the sediment near the corrals. The temperature of the bottom water was measured in the subtidal with a second data-logger. The data were analysed with the program Boxcar 6.0. The turbidity of the water (using a Secchi disc) was measured monthly in the subtidal.
Qualitative assessment of fisheries by interviews: To obtain information about the fishery of $M$. squalida, some randomly selected fishing grounds near the town of Puerto San Carlos (Fig. 1) were observed and people operating here were interviewed about their capture methods, the size and amounts of their catch and market issues (Table 1).

\section{RESULTS}

Densities and size distribution: The sampling efficiency obtained during regular sampling was about $68 \%$ and densities were corrected accordingly using a factor of 1.47 . Average density at the exploited site SBnorth (2.45 $\pm 1.18 \mathrm{ind} /$ $\mathrm{m}^{2}$ ) was significantly higher (one way ANOVA, $\mathrm{p}=0.009)$ than at SBcontrol $(1.84 \pm 1.35 \mathrm{ind} /$ $\left.\mathrm{m}^{2}\right)$ while SBsouth $\left(1.81 \pm 1.61 \mathrm{ind} / \mathrm{m}^{2}\right)$ did not differ from the control site $(\mathrm{p}=0.923)$. SBnorth and SBsouth differed significantly $(\mathrm{p}=$ 0.017). Total average density from all sites was $2.01 \pm 1.41 \mathrm{ind} / \mathrm{m}^{2}$. Individual samples varied between 0 and $6.13 \mathrm{ind} / \mathrm{m}^{2}$ (Table 2). The length

TABLE 1

Questionnaire for chocolate clam fishermen (recreational/commercial). Bahía Magdalena, Mexico. 2002-2003

Date of interviews: January and February 2003

Number of interviews: 11

Recreational/commercial fisheries

- Where are you searching for chocolate clams?

- How often are you searching for chocolate clams?

- $\quad$ Do you search during the whole year?

- What method are you using to find the clams?

- Do you search alone or with a co-worker?

- How long do you search per day?

- $\quad$ Of what size is the area you are searching at?

- $\quad$ Do you have expenses like gasoline etc.?

- How many clams do you find per day?

- $\quad$ Of what average size are they?

- Do you find more/less/as many as clams than a few years ago?
Additional questions for fisheries

- Did you have to change the site you where searching at due to insufficient numbers?

- How many clams do you sell (per day/week etc.)?

- $\quad$ For how much do you sell your clams?

- Where do you sell them?

- How much of your catch do you consume (with your family)?

- $\quad$ Are you a member of a fishing co-operation?

- $\quad$ Do you have another job?

- Does your family depend on chocolate clam fishery?

- What is the percentage of chocolate clam fishery of your income? 
frequency histograms (Fig. 2) show two cohorts at each sampling site with a modal progression of the small cohort over the sampling period.

Length-mass relations: The length-total mass and length-tissue mass relations are shown in Fig. 3. Biomass of clams with different shell lengths calculated with these equations are given in Table 3 and refer to the population biomass.

Growth: Clams larger than $60 \mathrm{~mm}$ showed very little or no growth at all. The parameters $\mathrm{K}$ and $\mathrm{L}_{\infty}$ derived from the tagging data of clams smaller or equal $60 \mathrm{~mm}$ were $0.655 \pm 0.367$ and $83 \mathrm{~mm}$ respectively. The growth performance index derived from these values was $\phi=3.654$. As seen in Fig. 4, K-values varied for different length groups and also temporally, between 0 and 1.741 . Since the capacity of the Munroroutine of FISAT II was limited, 178 tagging data were chosen randomly and a semi-quantative growth curve was calculated (Fig. 5).

Mortality: Using $\mathrm{K}=0.655$ and $\mathrm{L}_{\infty}=83$ $\mathrm{mm}$ obtained from tagging data the mortality
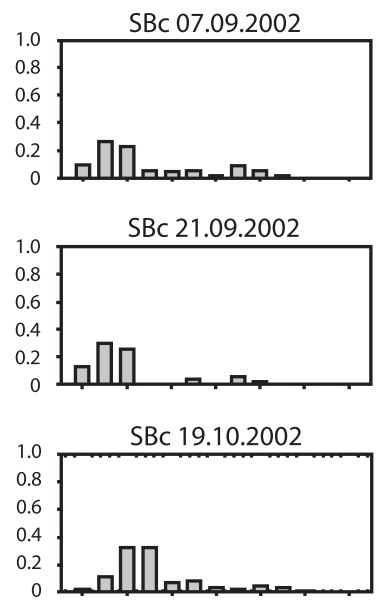

SBC 17.11.2002
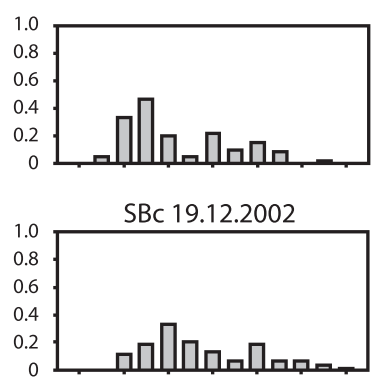

SBC 17.01.2003

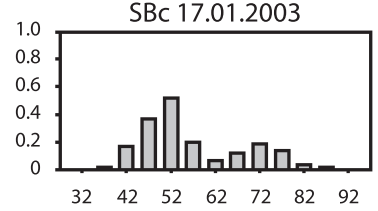

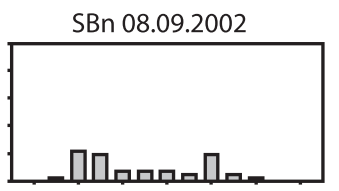

SBn 07.10.2002

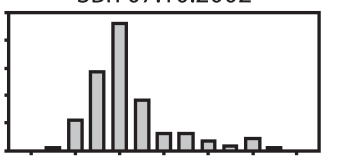

SBn 05.11.2002

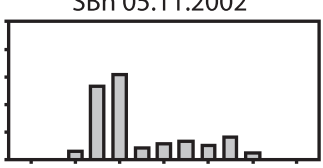

SBn 03.12.2002

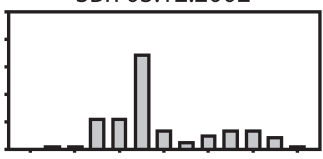

SBn 03.01.2003

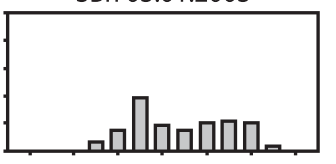

SBn 01.02.2003

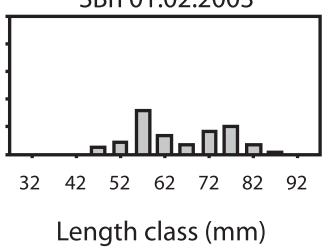

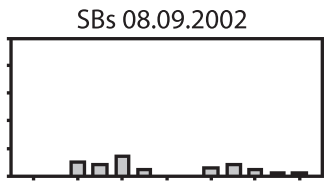

SBs 05.10.2002

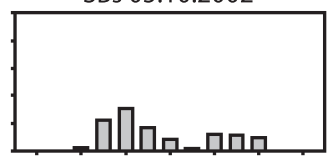

SBs 03.11.2002

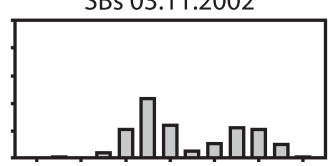

SBs 02.12 .2002

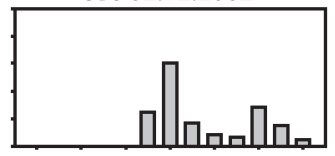

SBs 04.01.2003

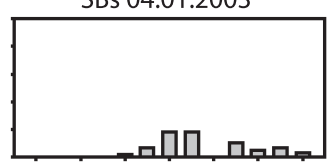

SBs 31.01.2003

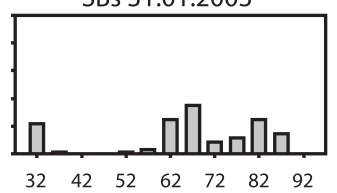

Fig. 2. Length frequency distributions of $M$. squalida at the three sampling sites SBcontrol (left), SBnorth (middle) and SBsouth (right). The frequency values represent the actual number of clams per $\mathrm{m}^{2}$. The catch efficiency is not taken into account. Bahía Magdalena, Mexico, 2002-2003. 
TABLE 2

Average clam density at the three sampling sites. Bahía Magdalena, Mexico, 2002-2003

$$
\text { Average density [ind } \left./ \mathrm{m}^{2}\right] \quad \text { SD } \quad \text { Average density corrected with } \quad \text { SD }
$$
factor $1.47\left[\mathrm{ind} / \mathrm{m}^{2}\right]$

$\begin{array}{llllr}\text { SBcontrol } & 1.25 & 0.92 & 1.84 & 1.35 \\ \text { SBnorth } & 1.67 & 0.80 & 2.45 & 1.18 \\ \text { SBsouth } & 1.24 & 1.10 & 1.81 & 1.61\end{array}$
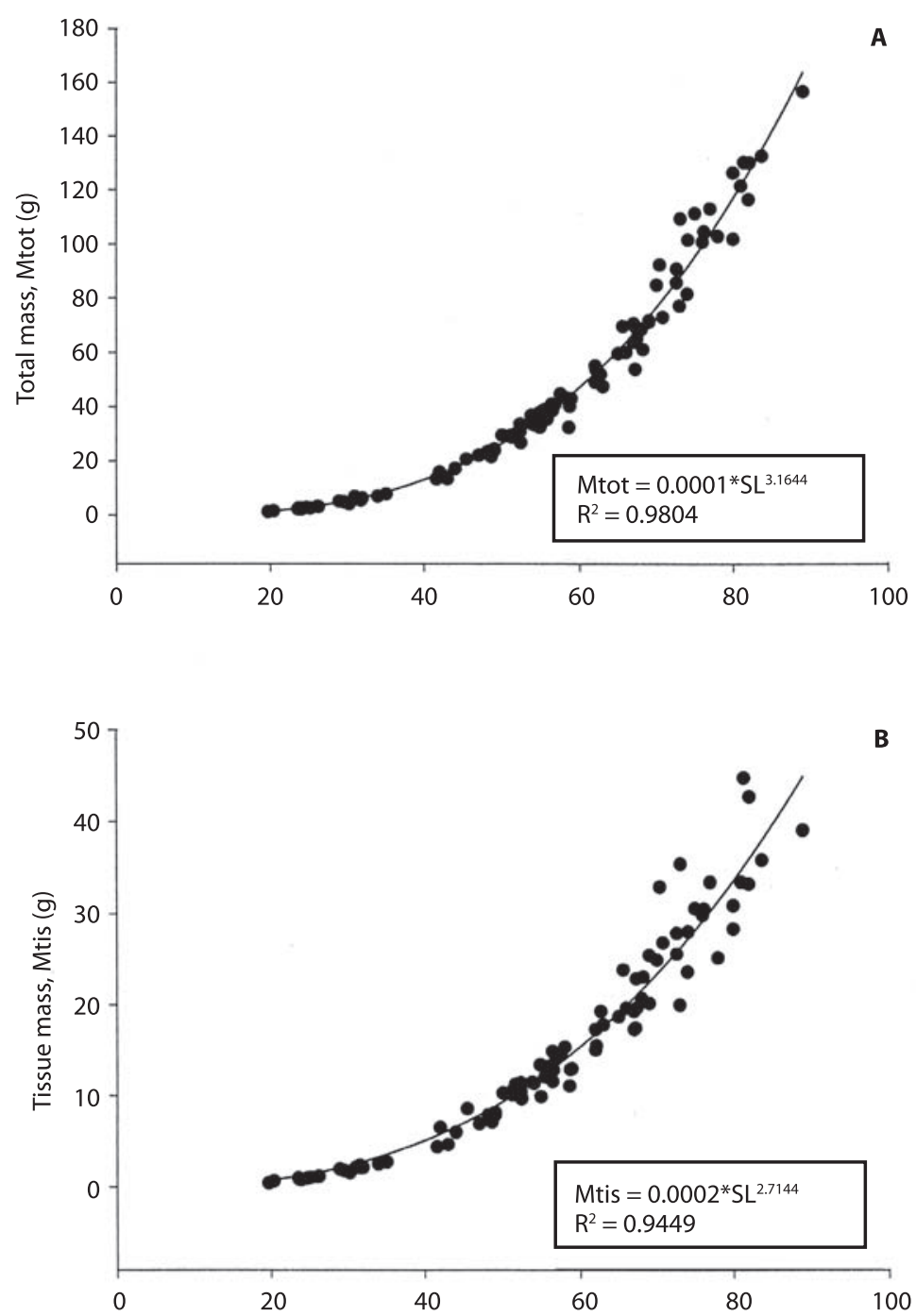

Fig. 3. Length-mass relation. A. Total mass. B. Tissue mass of M. squalida. Bahía Magdalena, Mexico, 2002-2003. 
TABLE 3

Length-mass relations of M. squalida calculated with obtained equations. Bahía Magdalena, Mexico, 2002-2003

Shell length $[\mathrm{mm}]$

10
30
50
70
90

Total mass [g]

$\begin{array}{cc}\text { This study } & \text { Singh et al. } \\ 0.15 & 0.51 \\ 4.72 & 9.92 \\ 23.78 & 39.42 \\ 68.96 & 97.83 \\ 152.76 & 192.87\end{array}$

Tissue mass [g]

$\begin{array}{cc}\text { This study } & \text { Singh } \text { et al. } \\ 0.10 & 0.25 \\ 2.04 & 3.00 \\ 8.18 & 9.55 \\ 20.39 & 20.5 \\ 40.33 & 36.27\end{array}$

Values at the right show relations found by Singh-Cabanillas et al. (1991) in the Bay of La Paz.
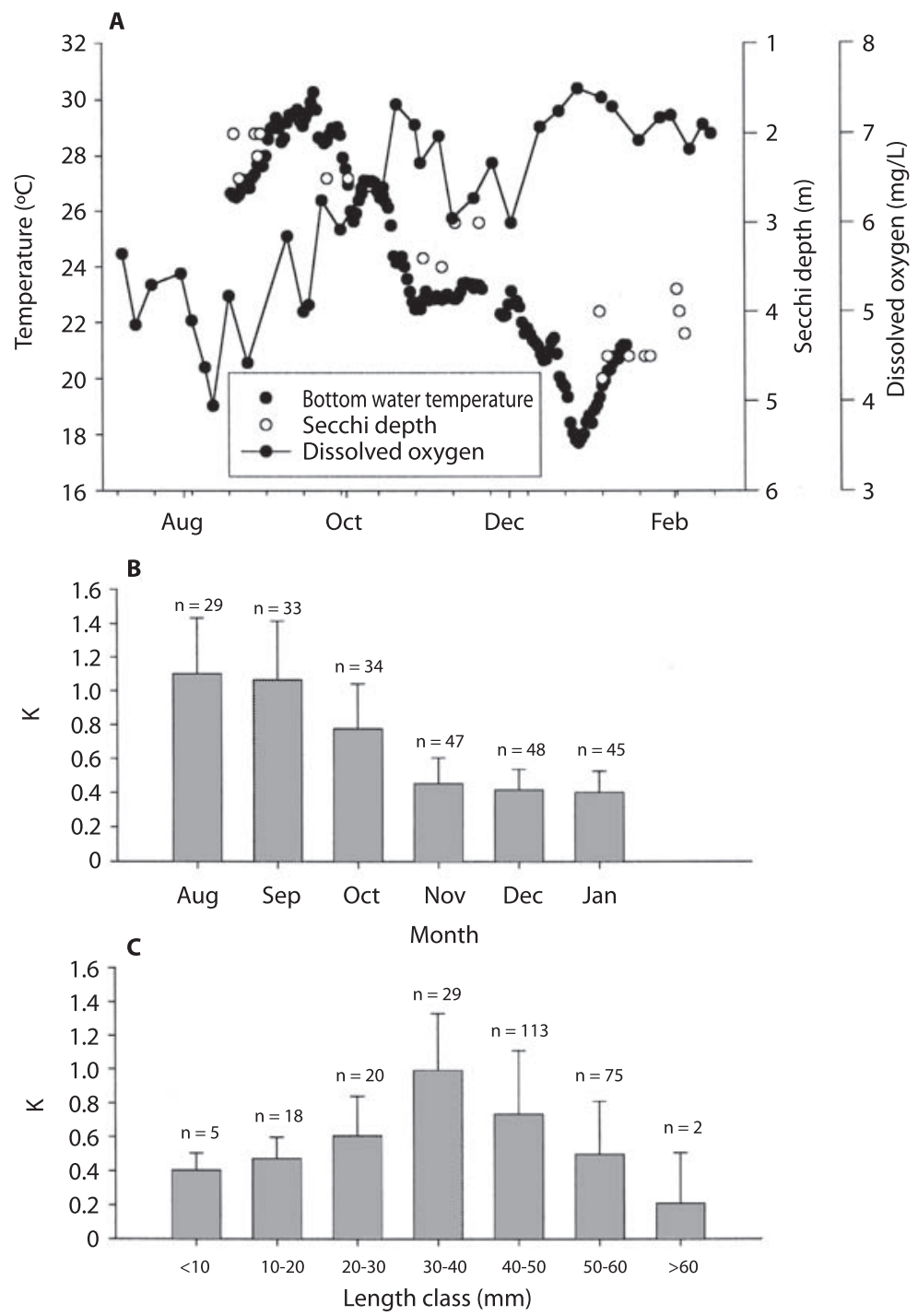

Fig. 4. A. Environmental conditions at SBcontrol over the study period. B. Monthly average k-values of tagged M. squalida specimens. C. Average K-values of different size classes. Bahía Magdalena, Mexico, 2002-2003. 


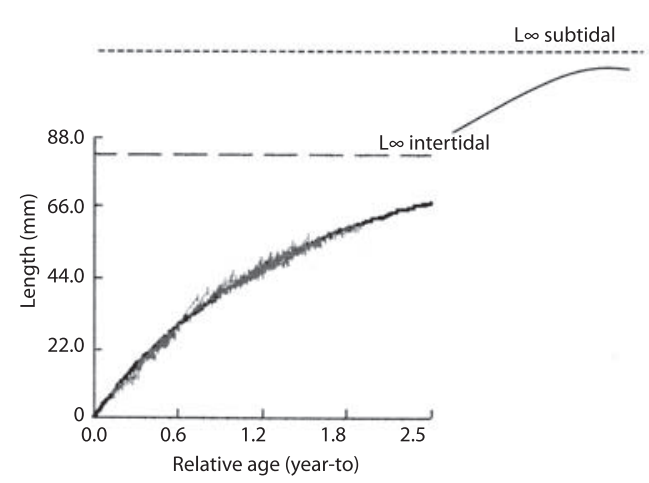

Fig. 5. Semi-quantative growth curve for M. squalida populations at the intertidal and subtidal zone. Bahía Magdalena, Mexico, 2002-2003.

rate ' $\mathrm{Z}$ ' at the unexploited site SBcontrol was $2.18 \mathrm{y}^{-1}$ (confidence interval $\mathrm{CI}=1.53-2.82$ ). The exploited sites SBnorth and SBsouth show lower mortality rates (SBnorth $\mathrm{Z}=1.38 \mathrm{y}^{-1}$ (0.30-2.46), SBsouth $\mathrm{Z}=1.71 \mathrm{y}^{-1}(-0.54-3.96)$ ). The value for ' $Z$ ' of the pooled data for all sampling sites is $1.61 \mathrm{y}^{-1}(\mathrm{CI}=1.37-1.85)$.

Vertical zonation: The box plots (Fig. 6) show an increase of mean length with increasing distance to the starting point. An ANOVA shows significant differences between the 40 and $60 \mathrm{~m}$ transects at SBcontrol $(\mathrm{p}=0.002)$, at SBnorth between 40 and $80 \mathrm{~m}(\mathrm{p}=0.003)$ and 60 and $80 \mathrm{~m}(\mathrm{p}=0.0006)$ and at Sbsouth between 40 and $60 \mathrm{~m}(\mathrm{p}=0.016)$ and 60 and $80 \mathrm{~m}(\mathrm{p}=0.009)$.

Migration: 20 tagged specimens of $M$. squalida could be recaptured after 69 days and 15 again after 143 days. Distances varied between 0.08 and $1.4 \mathrm{~m}$ after 143 days. Average distance was $0.48 \pm 0.33 \mathrm{~m}$ per 143 days (3.24 mm per day). Most of the clams showed seaward directed movement (Fig. 7).

Environmental conditions: The dissolved oxygen ranged between $3.95 \mathrm{mg} / \mathrm{ml}$ in August 2002 and $7.50 \mathrm{mg} / \mathrm{ml}$ in December 2002 (Fig. 4A). The temperature of the sediment and the bottom water were almost identical. As there was more data available on the bottom water temper-
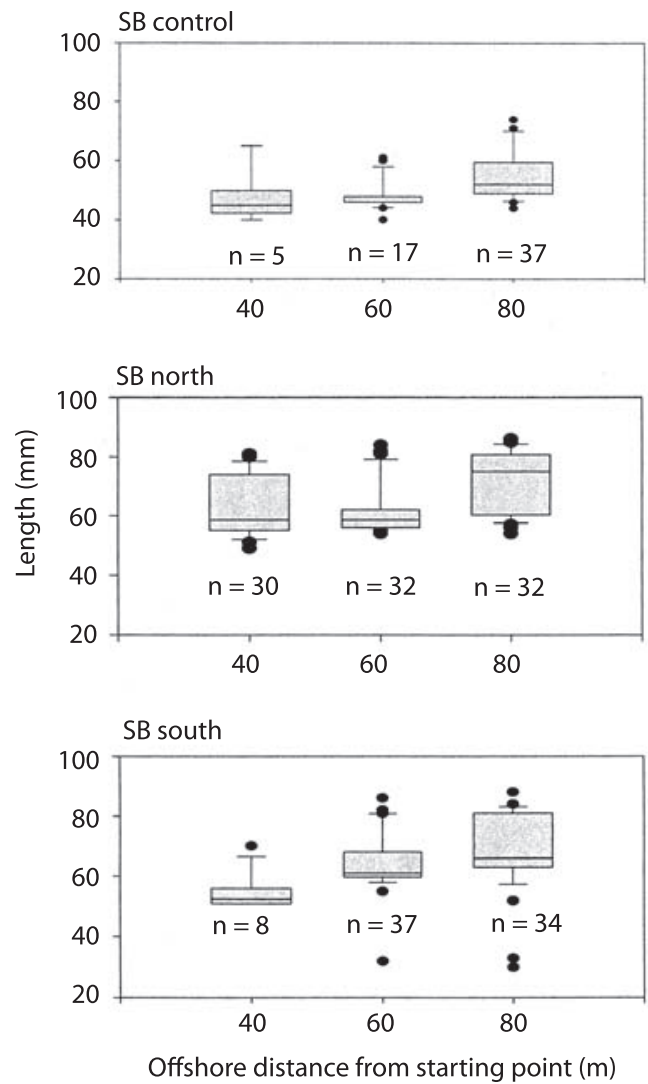

Fig. 6. Shell length (ranges and mean values) along transects at increasing distance from the shore. Bahía Magdalena, Mexico, 2002-2003.

ature, this data was considered. A maximum was reached at the end of September $\left(30.3^{\circ} \mathrm{C}\right)$ and a minimum at the end of December $\left(17.7^{\circ} \mathrm{C}\right)$. Average temperature of the sampling period was $24.3^{\circ} \mathrm{C}$. Secchi depth increased over the study period from $2 \mathrm{~m}$ to more than $5 \mathrm{~m}$.

Qualitative assessment of fisheries by interviews: 11 fishermen were interviewed. Two of them were professional chocolate clam fishermen who depend exclusively on the $M$. squalida fishery. Their fishing grounds are located in the channel in front of Puerto San Carlos. The size limit for chocolate clams is $60 \mathrm{~mm}$ shell length. The clams are collected by Hooka diving with the help of a co-worker in shallow water depths, bigger clams (up to 135 $\mathrm{mm}$ ) are generally found in deeper waters (up 


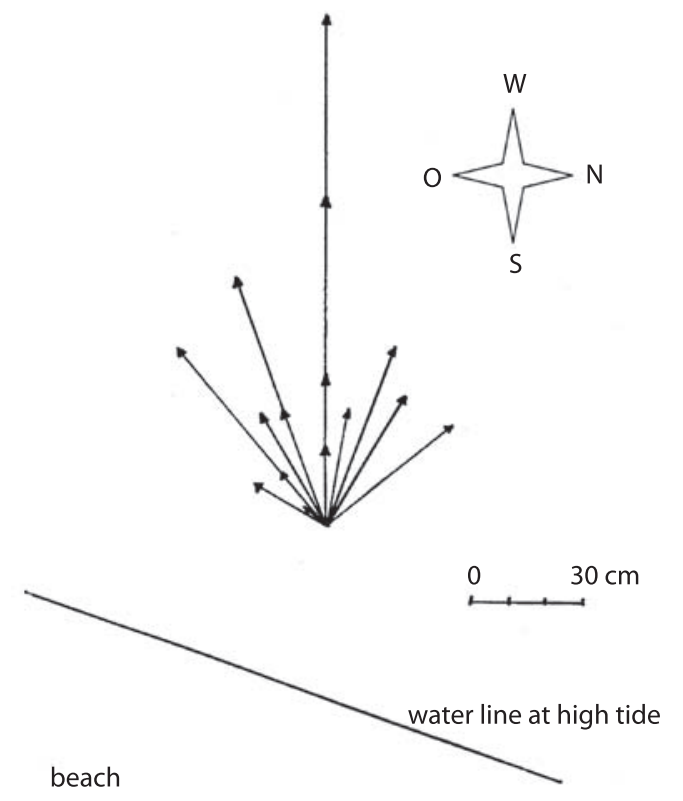

Fig. 7. Bearing of recaptured clams of the migration experiment after 143 days. The distance between water line at high tide and starting point does not correspond to scale. Bahía Magdalena, Mexico, 2002-2003.

to $10 \mathrm{~m}$ ). There they find six clams per $\mathrm{m}^{2}$ on average. Observations of the fishermen show that bigger clams appear in coarse sediments whereas smaller ones seem to prefer fine sand. One of the fishermen was fishing six days of the week for chocolate clams. Up to 900 individuals with an average size of $99 \mathrm{~mm}$ were caught per day and sold directly in Puerto San Carlos or on the regional or national market.

The recreational fishery of $M$. squalida is common in Puerto San Carlos. Seven of nine interviewed people search chocolate clams; five of them every two weeks at the time of spring low tides. In total, four different collecting sites were named: Estero San Buto, La Curva near San Carlos, Banderitas (another mangrove channel) and the sandflat in front of the boating ramp of San Carlos. They collect 50-200 clams per catch of an average length of $60 \mathrm{~mm}$, which are used exclusively for private consumption. Just one of the fishermen claimed to find less clams than before, the other persons did not observe a decline of the of the M. squalida population.

\section{DISCUSSION}

The average densities of $M$. squalida at the three sampling sites with 1.81-2.45 ind/ $\mathrm{m}^{2}$ were similar to densities found in Bahía Loreto by Gutiérres-Barreras et al. (1998) with $1-3 \mathrm{ind} / \mathrm{m}^{2}$. The distribution of $M$. squalida in San Buto was patchy, with 0-6.13 ind $/ \mathrm{m}^{2}$. High patchiness was also found in other studies (Baqueiro-Cárdenas and Stuardo 1977, Baqueiro-Cárdenas et al. 1982) who recorded chocolate clam densities from $0.04-10 \mathrm{ind} / \mathrm{m}^{2}$ at different sites in Baja California and seems to be the rule in $M$. squalida. Several factors might explain this high patchiness:

1. Baqueiro-Cárdenas (1979) studied the distribution of $M$. squalida, M. aurantiaca and Dosinia ponderosa in relation to the grain size of the sediment. $M$. squalida was found in coarse to fine sand and its relative abundance decreased in coarse sand. García-Domínguez (1991) observed that the distribution of Chione californiensis, which is often found in assemblage with M. squalida, is also determined by the type of substrate. The grain size could influence the burrowing rate of the chocolate clam which has been observed for other bivalves (Alexander et al. 1993, Nel et al. 2001) and could thereby influence the ability of M. squalida to evade its predators or to reach the sediment surface after burial by storm deposits or by tidal sedimentation. In addition, the substrate selectivity off settling larvae could play a role (Alexander et al. 1993). It was shown by Norkko et al. (2001) that several juvenile bivalves (0.5-4 $\mathrm{mm}$ length) dispersed over scales of meters within one tidal cycle. Nothing is known about dispersal of juvenile specimens of $M$. squalida but adult chocolate clams are able to move several decimeters in a few months as was observed in the migration experiment of this study.

2. Intraspecific competition could also be influencing the distribution of $M$. squalida 
and may explain the high patchiness. Adults could filter passively settling larvae and therefore inhibit settlement and subsequent recruitment (Defeo 1996, Brazeiro and Defeo 1999). The density of adults could also limit the survival of settled juveniles as they are not able to compete for food with the same efficiency as the adults (SearcyBernal and Juárez-Romero 1991).

3. Patchy occurrence of predators could lead to patchy distributions of $M$. squalida on a very small scale.

In the available studies about the abundance of $M$. squalida, there is few comparable data about sampling efficiency. At the present study $68 \%$ in average could be detected. A recapture of $61.6 \%$ of 237 tagged specimens of M. squalida by Castro-Ortiz et al. (1992) at two sites at Bahía Concepción shows a similar efficiency. Clams of all size classes were overlooked in our study although sampling was done very thoroughly.

The length-total mass relation of $M$. squalida was different from that found by Singh-Cabanillas et al. (1991) in the bay of La Paz whereas length-tissue mass relation was similar. As seen in Table 3, total weight of a chocolate clam of $50 \mathrm{~mm}$ length would be $23.78 \mathrm{~g}$ (tissue mass $8.18 \mathrm{~g}$ ) in this study. After the length-mass relation found by SinghCabanillas et al. (1991), it would be $39.42 \mathrm{~g}$ (tissue mass $9.55 \mathrm{~g}$ ). These differences might be explained by different methods. SinghCabanillas et al. (1991), did not freeze specimens of $M$. squalida before weighing. This might have led to a higher proportion of water in the clams resulting in higher total mass than found in clams of the recent study. In addition, high variation of individual length-mass ratio could have an influence. In this study, variations in mass of more than $30 \%$ were found in clams of the same length.

Sampling of transects showed a general trend to larger chocolate clams in deeper water (Fig. 6). Though no transects were sampled in the subtidal area, observation of the commercial fishery lead to the conclusion, that average size of $M$. squalida specimens increases with increasing water depths. Individuals of more than $135 \mathrm{~mm}$ could be found in water depths of more than $10 \mathrm{~m}$. It was observed that average size of 163 clams of a commercial catch in deeper water was $107 \mathrm{~mm}$. This phenomenon was also described by Donn (1990) for Donax serra, a sediment-burrowing bivalve inhabiting southern African coasts who observed small individuals high on the shore and larger ones progressively further down. This author suggests that the different zonation patterns were due to a change of behavior/response of clams with increasing size. It could be possible that small individuals prefer the upper intertidal to be better protected against aquatic predators. Larger clams might move to lower tidal levels because they are less vulnerable to predation and conditions for feeding and spawning are better (Bally 1983). The migration experiment of this study confirmed the ability of $M$. squalida to move and its preference to move in direction of the subtidal zone.

The relatively low $\mathrm{L}_{\infty}$ found in this study at the intertidal and the high $\mathrm{L}_{\infty}$ of chocolate clams at the subtidal area strongly suggest that intertidal and subtidal populations should be considered separately. After small clams of the intertidal zone reach $\mathrm{L}_{\infty}$ of about $83 \mathrm{~mm}$ their growth ceases and the clams migrate to the subtidal area, where growth continues due to better food availability and more constant environmental conditions (Fig. 5). Another possible explanation could be settlement of larvae in deeper waters, where specimens reach up to $135 \mathrm{~mm}$ due to better conditions. In conclusion, clam size seems to be highly dependent on the habitat and water depth.

The two distinct cohorts in the length frequency histograms may represent two consecutive year classes. According two the growth parameters determined in the tagging experiment, $M$. squalida is a moderately slow growing species and large individuals $(\sim 82 \mathrm{~mm})$ may be up to seven years old. Using the average growth parameters $\mathrm{L}_{\infty}=83 \mathrm{~mm}$ and $\mathrm{K}=$ 0.655 , a $50 \mathrm{~mm}$ clam would be approximately 
1.4 years old, a $70 \mathrm{~mm}$ shell 2.8 years. The two distinct peaks shown at the histograms could refer to these age groups. This might be a sign for one main spawning pulse per year. Although $M$. squalida reproduces throughout the year, one or two periods of increased spawning were usually mentioned in most previous studies. However, reproduction patterns varied between populations at different sites (Baqueiro-Cárdenas and Stuardo 1977, SinghCabanillas et al. 1991, Villalejo-Fuerte et al. 1996, Villalejo-Fuerte et al. 2000).

The average $\mathrm{K}$-value $=0.655$ and $\mathrm{L}_{\infty}=$ $83 \mathrm{~mm}(\phi=3.654)$ obtained with tagging data of this study are similar to the average $\mathrm{K}=$ 0.551 and $\mathrm{L}_{\infty}=81 \mathrm{~mm}(\phi=3.558)$ found by Castro-Ortiz et al. (1992) in El Remate, Bahía Concepción. These growth parameters differ considerably from $\mathrm{K}=0.152$ and $\mathrm{L}_{\infty}=86 \mathrm{~mm}$ $(\phi=3.051)$ found at a different site in the same study of Castro-Ortiz et al. (1992). The two sampling sites in Bahía Concepción showed different sediment properties and different current velocities. Other studies reported faster growth of $M$. squalida. While juveniles of $25 \mathrm{~mm}$ with $\mathrm{K}$ $=0.655$ and $\mathrm{L}_{\infty}=83 \mathrm{~mm}$ would increase approximately $3 \mathrm{~mm}$ per month in Estero San Buto, Baqueiro-Cárdenas and Stuardo (1977) found growth rates of $4.5 \mathrm{~mm}$ in these size classes, and Singh-Cabanillas et al. (1991) even 5 mm per month. These studies were conducted in the Bay of La Paz (Gulf of California) and in the south of Mexico (Guerrero), sites with higher annual mean temperatures than San Buto. The growth of $M$. squalida seems to be highly dependent on geographical differences of parameters such as temperature, sediment properties and currents. It has to be taken into account that densities of $M$. squalida in the fenced in areas were high (4-20 ind $/ \mathrm{m}^{2}$, juveniles $<20 \mathrm{~mm}: 92 \mathrm{ind} / \mathrm{m}^{2}$ ) which might have negatively influenced the growth of the clams. Still, clam biomass in the corrals was similar to clam biomass in the field as most of other abundant bivalves such as Chione californiensis (densities of about $48 \mathrm{ind} / \mathrm{m}^{2}$ found by Castro-Ortiz and García-Domínguez 1993) were removed from the corrals.
Growth of M. squalida was strictly seasonal (Fig. 4b). K-values decreased with decreasing temperature, increasing oxygen content and increasing secchi depth of the water (Fig. 4). The decreasing turbidity observed during the study is a sign for decreasing food availability and might be a limiting factor for filter-feeders such as M. squalida. Since it is a tropical species and found on its northernmost distribution limit, temperature plays an more important role in its development. In conclusion the growth seems to be positively correlated with food availability and temperature. Castro-Ortiz et al. (1992) and Baqueiro-Cárdenas and Stuardo (1977) observed a seasonal growth of M. squalida with highest growth rates in June in Bahía Concepción and Bahía Zihuatanejo. Seasonality could also be observed for other venerid clams like Chione californiensis which can be found associated with $M$. squalida (Castro-Ortiz and García-Domínguez 1993). Another venerid clam that can be found at the coast of Baja California is Tivela stultorum. This species showed seasonal growth in California populations (Coe and Fitch 1950) but slower winter growth was not observed in T. stultorum inhabiting beaches in Baja California, its southernmost limit of distribution (Searcy-Bernal and Saavreda-Rosas 1988).

A strong individual variation of K-values (Fig. 4) within one population at the same site under the same environmental conditions was observed. K-values varied between 0 and 1.741. Standard deviation of $\mathrm{K}$ was very high $(\mathrm{K}=0.655 \pm 0.367)$. This phenomenon makes it difficult to predict individual growth and it is necessary to sample a high number of clams throughout the year to obtain more reliable growth parameters.

Total mortality $\mathrm{Z}$ was high at all sampling sites (pooled data: $1.61 \mathrm{y}^{-1}$ ). Contrary to our expectations, mortality rate at the exploited sites was lower than at the control site. Consequently, exploitation must have been too small to be recognizable and the calculated total mortality should equal the natural mortality rate $\mathrm{M}$ at the sampling sites in San Buto. 
The natural mortality $\mathrm{M}$ of $M$. squalida is high in comparison to other bivalves. Venus antiqua showed natural mortality of $\mathrm{M}=0.33 \mathrm{y}^{-1}((\phi=$ 3.07) in Southern Chile (Clasing et al. 1994)). Similar mortality and growth parameters could be found for Mesodesma mactroides $\mathrm{M}=1.64$ $\mathrm{y}^{-1}(\phi=3.67)$ on Uruguayan beaches (Defeo et al. 1992).

As mentioned above, the patchy distribution of $M$. squalida makes it more difficult to determine an impact of fishery. However, the analysis of the fishery itself did not reveal an overexploitation of $M$. squalida in the intertidal zone. Out of 11 interviewed persons just one professional fisherman claimed to have observed an decrease in chocolate clam abundances. This is surprising due to the high demand of the clam and its heavy exploitation at several points of the bay.

Although the recreational fishery at San Buto takes place mostly in summer (May-July) (pers. obs.), its impact on density and size distribution should have been observable in the following months, which was not the case. The exploitation of the sampling sites at San Buto might have been lower in comparison to more heavily exploited areas at other parts of the bay and therefore the impact might have been too small to be recognizable. Another possible explanation could be the early maturity of clams which was observed in individuals of 42 mm length (Villalejo-Fuerte et al. 1996) and the limitation of the fishery to specimens larger than $60 \mathrm{~mm}$, which was also the average shell length of specimens harvested by recreational fishermen. Early maturity and reproduction throughout the year may enable $M$. squalida to compensate the fishing pressure. Furthermore, sampling efficiency at the intertidal, which is presumably higher than fishing efficiency, was about $68 \%$ of clam stock. The remaining clams might be sufficient to keep the intertidal population stable. However, the absence of clear indications of overfishing should not be taken as a proof that the population is in a healthy state, as data was only gathered over a period of six months and the spatial scale was not extensive enough to be able to draw conclusions.

Therefore, further studies with a strong emphasis on the fishery of $M$. squalida in the subtidal should be conducted, as the large specimens play an important role in the commercial fishery.

\section{ACKNOWLEDGMENTS}

The authors gratefully acknowledge the financial and logistic support provided by the School for Fieldstudies, Center for Coastal Studies, Puerto San Carlos and the Center for Tropical Marine Ecology (ZMT), Bremen. Special thanks go to Marc H. Taylor for his help and advice in fieldwork.

\section{RESUMEN}

Se estudió la dinámica poblacional de la almeja Megapitaria squalida de setiembre 2002 a febrero 2003 en Bahía Magdalena, México. La densidad se determinó en un sitio no explotado y dos sitios explotados utilizando transectos perpendiculares desde la línea costera. También se entrevistó a pescadores locales de diferentes partes de la bahía para obtener información acerca de la pesquería artesanal y recreacional de $M$. Squalida. La densidad promedio estimada fue de $2.01 \pm 1.41 \mathrm{ind} / \mathrm{m}^{2}$, sin diferencias significativas entre sitios. La relación de masa y longitud total fue de $\mathrm{M}_{\text {tot }}=0.0001 * \mathrm{SL}^{3.1644}\left(\mathrm{r}^{2}=0.9804, \mathrm{n}=92\right)$ y la relación de masa y longitud de tejido fue de $\mathrm{M}_{\text {tis }}=0.0002 * \mathrm{SL}^{2.7144}$ $\left(r^{2}=0.945, n=92\right)$. Los parámetros de crecimiento Von Bertalanffy se determinaron utilizando marcadores individuales. Hay grandes diferencias en crecimiento tanto interindividuales como estacionales. Los valores anuales promedio fueron: $\mathrm{K}=0.655, \mathrm{~L} \infty=83 \mathrm{~mm}$. Debido a que la longitud de la concha puede superar los $135 \mathrm{~mm}$ en aguas profundas, es necesario considerar las poblaciones intermareal e inframareal de manera separada. La mortalidad promedio total (Z) fue de $1.61 \mathrm{y}^{-1}$. No se calculó la mortalidad de pesca porque la mortalidad total (Z) del sitio no explotado fue mayor que la de sitios explotados. Aparentemente $M$. squalida migra hacia aguas más profundas al crecer. No se encontró evidencia de que estas poblaciones estén sobreexplotadas.

Palabras clave: Megapitaria squalida, Veneridae, dinámica poblacional, intermareal, Bahía Magdalena, México. 


\section{REFERENCES}

Alexander, R.R., R.J. Stanton \& J.R. Dodd. 1993. Influence of sediment grain size on the burrowing of bivalves: correlations with distribution and stratographic persistence of selected neogene clams. Palaios 8: 289-303.

Alvarez-Borrego, S., L.A. Galindo-Bect \& A. CheeBarragan. 1975. Características Hidroquímicas de Bahía Magdalena, B.C.S. Cien. Mar. 2: 94-109.

Bally, R. 1983. Intertidal zonation on sandy beaches of the west coast of South Africa. Cah. Biol. Mar. 24: 85-103.

Baqueiro-Cárdenas, E. 1979. Sobre la distribución de Megapitaria aurantiaca (Sowerby), M. squalida (Sowerby) y Dosinia ponderosa (Gray) en relación a la granulometría del sedimento (Bivalvia: Veneridae): Nota científica. An. Centro Cien. Mar Limnol. UNAM 6: 25-32.

Baqueiro-Cárdenas, E. \& J. Stuardo. 1977. Observaciones sobre la Biología, Ecología y Explotación de Megapitaria aurantiaca (Sowerby, 1831), M. squalida (Sowerby, 1835) y Dosinia ponderosa (Gray, 1838) (Bivalvia: Veneridae) de la Bahiá de Zihuatanejo e Isla Ixtapa, Gro., México. An. Centro Cien. del Mar y Limnol. UNAM 4: 161-208.

Baqueiro-Cárdenas, E., J.A. Masso R. \& H. Guajardo B. 1982. Distribución y abundancia de moluscos de importancia comercial en Baja California Sur. Instituto Nacional de la Pesca, México. Serie de divulgación 11.32 p.

Baqueiro-Cárdenas, E. \& D. Aldana-Aranda. 2000. A review of reproductive patterns of bivalve mollusks from Mexico. Bull. Mar. Sci. 66: 13-27.

Brazeiro, A. \& O. Defeo. 1999. Effects of harvesting and density dependence on the demography of sandy beach populations: the yellow clam Mesodesma mactroides of Uruguay. Mar. Ecol. Prog. Ser. 182: 127-135.

Castro-Ortiz, J.L., A. Tripp-Quezada \& B. Anguas-Vélez. 1992. Crecimiento de la almeja chocolata Megapitaria squalida (Sowerby, 1835) en Bahía Concepción, Baja California Sur, México. Inv. Mar. CICIMAR 7: 1-7.

Castro-Ortiz, J.L. \& F. García-Domínguez. 1993. Crecimiento de Chione californiensis (Broderip, 1835) (Veneridae) en la Ensenada de La Paz, Baja California Sur, México. Inv. Mar. CICIMAR 8: 45-52.

Clasing, E., T. Brey, R. Stead, J. Navarro \& G. Asencio. 1994. Population dynamics of Venus antiqua
(Bivalvia: Veneridae) in the Bahía de Yaldad, Isla de Chiloé, Southern Chile. J. Exp. Mar. Biol. Ecol. 177: 171-186.

Coe, W.R. \& J.E. Fitch. 1950. Population studies, local growth rates and reproduction of the Pismo clam (Tivela stultorum). J. Mar. Res. 9: 188-210.

Cruz-Agüero, J. de la, F. Galván-Magaña, L.A. AbitiaCárdenas, J. Rodriguez-Romero \& F.J. GutiérrezSánchez. 1994. Systematic List of Marine Fishes from Bahía Magdalena, Baja California Sur (Mexico). Cien. Mar. 20: 17-31.

Defeo, O. 1996. Recruitment variability in sandy beach macroinfauna: much to learn yet. Rev. Chil. Hist. Nat. 96: 615-613.

Defeo, O., E. Ortiz \& J.C. Castilla. 1992. Growth, mortality and recruitment of the yellow clam Mesodesma mactroides on Uruguayan beaches. Mar. Biol. 114: 429-437.

Donn, T.E. 1990. Zonation Patterns of Donax serra Röding (Bivalvia: Donacidae) in Southern Africa. J. Coast. Res. 6: 903-911.

García-Domínguez, F. 1991. Distribución, abundancia, reproducción y fauna asociada de la almeja roñosa, Chione californiensis, en la Ensenada de La Paz, B.C.S., México. Tesis de Maestría, Universidad de Colima, La Paz, Baja California Sur, México. 136 p.

Gayanilo, F.C., P. Sparre \& D. Pauly. 1994. The FAOICLARM Stock Assessment Tools (FISAT) user's guide. Final Draft, FAO, Rome. ICLARM Contr. 1084 p.

Gulland, J.A. 1988. Fish population dynamics. Wiley \& Sons, Chichester, 2. ed., 422 p.

Keen, A.M. 1971. Sea Shells of Tropical West America. Marine Mollusks from Baja California to Peru. Stanford University, Stanford, California, USA, 1064 p.

Munro, J.L. 1982. Estimation of the parameters of the von Bertalanffy growth equation from recapture data at variable time intervals. J. Cons. CIEM 40: 199-200.

Nel, R., A. McLachlan \& D.P.E. Winter. 2001. The effect of grain size on the burrowing of two Donax species. J. Exp. Mar. Biol. Ecol. 265: 219-238.

Norkko, A., V.J. Cummings, S.F. Thrush, J.E. Hewitt \& T. Hume. 2001. Local dispersal of juvenile bivalves: implications for sandflat ecology. Mar. Ecol. Prog. Ser. 212: 131-144.

Pauly, D. \& J.L. Munro. 1984. Once more on the comparison of growth in fish and invertebrates. Fishbyte 2: 21. 
Searcy-Bernal, R. \& A. Saavreda-Rosas. 1988. Population studies of the pismo clam Tivela stultorum in a beach of Baja California, Mexico. Cien. Mar. 14: 1-14.

Searcy-Bernal, R. \& R. Juárez-Romero. 1991. Length and age structure in commercial catch samples of the pismo clam clam Tivela stultorum (Mawe, 1823), from Playa San Ramon, B.C., Mexico. Cien. Mar. 17: 71-82.

Singh-Cabanillas, J., J.A. Vélez-Barajas \& Ma. del C. Fajardo-Léon. 1991. Estudio poblacional de la almeja chocolata Megapitaria squalida (Sowerby, 1835) en Punta Coyote, Bahía de La Paz, B.C.S., México. Ciencia Pesquera, Inst. Nal. de la Pesca. Serie de Pesca. México 8: 7-22.

Villalejo-Fuerte, M., G. García-Melgar, R.I. Ochoa-Báez \& A. García-Gasca. 1996. Ciclo reproductivo de Megapitaria squalida (Sowerby, 1835) (Bivalvia: Veneridae) en Bahía Concepción, Baja California Sur, México. INPA Boletín Científico 4: 29-39
Villalejo-Fuerte, M., M. Arellano-Martínez, B.P. CeballosVázquez \& F. García-Domínguez. 2000. Ciclo reproduvtivo de la almeja chocolata Megapitaria squalida (Sowerby, 1835) (Bivalvia: Veneridae) en Bahía Juncalito, Golfo de California, México. Hidrobiológica 10: 165-168.

\section{INTERNET REFERENCES}

Gutiérrez-Barreras, J.A., M. Maldonado-Diaz, M. Villalejo-Fuerte, M. Mandujano-Herrera \& B. Bermúdez-Almada. 1998. Evaluación de la almeja chocolata Megapitaria squalida (Sowerby, 1835) (Bivalvia: Veneridae) en el Parque Nacional Bahía de Loreto, Golfo de California. (Abstract). (Downloaded: September 14, 2002, http://aimac. ens.uabc.mx/aim/conferencias/Biol-Ecol/formatoHTML/lr-041.htm). 
